\title{
Using Nonconventional Water in Irrigation of Olive Trees and Its Effect on Olive Oil Properties
}

\author{
Zaher Barghouthi ${ }^{*}$, Abdallah Alimari1,2, Mohannad Qurie ${ }^{3}$, Sameer Amereih ${ }^{4}$, \\ Jamal Y. Al-Dadah ${ }^{5}$ \\ ${ }^{1}$ National Agricultural Research Center (NARC), Jenin, Palestine \\ ${ }^{2}$ International Center for Agricultural Research in Dry Areas (ICARDA), Jenin, Palestine \\ ${ }^{3}$ Center for Chemical and Biological Analysis, Al-Quds University, East Jerusalem, Palestine \\ ${ }^{4}$ Palestine Technical University-Kadoori, Tullkarm, Palestine \\ ${ }^{5}$ Palestinian Water Authority, Gaza, Palestine \\ Email: *zaher_bar@hotmail.com
}

How to cite this paper: Barghouthi, Z., Alimari, A., Qurie, M., Amereih, S. and Al-Dadah, J.Y. (2017) Using Nonconventional Water in Irrigation of Olive Trees and Its Effect on Olive Oil Properties. Journal of Agricultural Chemistry and Environment, 6, 222-231.

https://doi.org/10.4236/jacen.2017.64015

Received: October 4, 2017

Accepted: November 20, 2017

Published: November 23, 2017

Copyright $\odot 2017$ by authors and Scientific Research Publishing Inc. This work is licensed under the Creative Commons Attribution International License (CC BY 4.0).

http://creativecommons.org/licenses/by/4.0/

\begin{abstract}
The response of olive orchard with same age and type to irrigation with treated municipal wastewater and freshwater was investigated in three years. Physical and chemical properties of the treated municipal wastewater reuse in agriculture (the effluent) produced by the Sheikh Ejleen wastewater treatment plant in Gaza Strip, freshwater, soil, and olive oil were determined and compared with Palestinian and international standards. The biological oxygen demand (BOD) of Sheikh Ejleen effluent is $60 \mathrm{mg} \cdot \mathrm{l}^{-1}$, which indicates low quality effluent. The results indicate that most of olive oil quality parameters-including heavy metals and trace elements for both fruits irrigated with treated wastewater or irrigated with freshwater-fall within the acceptable standard limit values. Moreover, soil analysis shows that organic content and cation exchange capacity were improved in soil irrigated with treated wastewater in comparison with that irrigated with freshwater. The results also show that there is no trace elements or heavy metals accumulation in soil.
\end{abstract}

\section{Keywords}

Irrigation, Nonconventional Water, Effluent, Olive Trees, Olive Oil, Gaza Strip

\section{Introduction}

Agriculture is an essential component of the Palestinian national, cultural, eco- 
nomic and social fabric. It is also important for Palestinians as it embodies their perseverance, confrontation and adherence to their land under the threat of confiscation and settlement activities [1]. Moreover, it supports the achievement of food security, provides employment for $11.5 \%$ of the labor force, contributes $5.6 \%$ to the gross domestic product (GDP), and accounts for $21 \%$ of total exports, in addition to its direct contribution to the improvement and preservation of the environment [2]. Approximately 183,000 hectares of land are used for agriculture, and nearly half of that is used for olive trees, employing large number of unskilled labour and about 15\% of working women. For many Palestinian farmers, olive trees and oil provide an important source of income. In fact, 80,000 to 100,000 families are said to rely on olives and olive oil for primary or secondary source of income [3] [4].

The olive tree is of great significance for Palestinians, as it has cultural, traditional and economic value. Harvest season was always seen as a joyful time for family and friends to gather. Palestine has some of the world's oldest olive trees, some dating back 4000 years. There are approximately 11 million olive trees accounting for $70 \%$ of fruit production in Palestine [5].

However, the agriculture sector is facing many challenges and obstacles. The political conflict in Palestine is the most critical of these challenges, characterized by the occupation practices of land confiscation, control over natural resources, and restriction on mobility of products between Palestinian areas on one hand; and with the international market on the other, hand. The agricultural sector is also suffering from the limited water sources, the access restrictions, and climate changes challenges [6]. Therefore, the agricultural sector's contribution to gross domestic product (GDP) has been declining over years, from $18.8 \%$ in 1987 to $4.1 \%$ in 2013 in Palestine, and to 3.4\% in the West Bank [6] [7]. Accordingly, olive oil production dropped from an average of 23,000 tons per year during the period 2000-2004 to 14,000 tons per year during the period 2007-2010 [7].

The Middle East countries are suffering from sharp shortage of water resources and increasing water demand due to increase of population and exploitation of the available water resources [8]. However, water crises in Palestine is felt most acutely than that in the middle east as the Palestinians suffer from both of water availability due to natural factors and from water accessibility due to political restrictions [9]. Furthermore, climate change, both increased temperature and decreased rainfall causing more frequent drought and increasing desertification, will significantly impact on Palestinian agriculture, food security and water availability [9] [10].

The increasing competition for good-quality water among different water-use sectors has reduced allocation of freshwater for agriculture [11]. In order to narrow the gap between freshwater demand and supply, farmers have to increasingly rely on use of nonconventional water (wastewater and saline water) for crop production, which represents an opportunity to save freshwater [9] [12] [13]. Palestinian national agricultural sector strategy for the period 2014-2016 
which is called "Resilience and Development" aims to increase the available water for agriculture by 30 million $\cdot \mathrm{m}^{3}$ by the end of $2016,15 \mathrm{million} \cdot \mathrm{m}^{3}$ of which is from nonconventional water [2]. Wastewater and saline water represent two potential sources for non-conventional water in Palestine.

On light of the above, treated wastewater effluent is one of the promising solutions in the integrated water management. It is less expensive and considered an attractive source of irrigation water. Moreover, it is considered a promising practice that helps in minimizing the pollution of the ecosystem subjected to contamination by direct disposal into surface or groundwater. In addition, treated wastewater is a valuable source for plant nutrients and organic matter needed for maintaining fertility and productivity of arid soils.

In the present work, treated wastewater of Sheikh Ejleen wastewater treatment plant is used to irrigate olive orchard in order to study its effect on olive oil properties, soil, environment, public health, etc., in comparison with reference sample of olive trees of the same type and age irrigated by fresh groundwater as control, then, quality of olive oil extracted from trees irrigated by different types of irrigation is compared.

\section{Methodology}

The experiment was conducted in Gaza strip at El-Zaitoun area in Shetawe's farm, and it's at $800 \mathrm{~m}$ from Gaza treatment plant, where a pilot project called Sheikh Ejleen Pilot Project for using the treated wastewater in irrigation of olive orchard.

\subsection{Study Area}

The Gaza Strip area is part of Palestine. It is a very small area of about $365 \mathrm{~km}^{2}$ located at the eastern coast of the Mediterranean, about $35 \mathrm{~km}$ long and between 6 to $12 \mathrm{~km}$ wide The Gaza Strip forms a transitional zone between the semi-humid coastal area in the north and the semi-arid Sinai desert in the south [8]. Sheikh Ejleen is a neighborhood in southern Gaza City near the coastal road. According to the Palestinian Central Bureau of Statistics (PCBS), the Palestinian population in the Gaza Strip at the end of 2016 was 1.91 million [14].

\subsection{Sheikh Ejleen Wastewater Treatment Plant}

Sheikh Ejleen wastewater treatment plant is a hybrid system consists of anaerobic lagoons, biotowers (attached growth biofilm), and activated sludge (suspended growth) wastewater plant that built in 1978 and redesigned and rehabilitated in 1996 to remove nutrients (carbonaceous, nitrogen, and phosphorous) from wastewater. It is located at Gaza Strip south of Gaza City on 140 dunums with a rated capacity of $60,000 \mathrm{~m}^{3} / \mathrm{d}$ (for design year 2020). The plant receives mostly residential wastewater. The partially-treated effluent is discharged to Mediterranean Sea. Currently there is a pilot reuse project of about $1000 \mathrm{~m}^{3} /$ day [15]. Several effluents samples were taken during the experiment for water quality analy- 
sis including physical, chemical and biological analysis according to the standard methods for the examination of water and wastewater [16].

\subsection{Field Experiment}

The olive orchard in Sheikh Ejleen-Gaza Strip was divided in to two parts of the same variety of olive trees (K18), the same age, and with the same olive fruit color, which is green. In each part, three lines of olive trees were considered as three replicates, and samples were taken randomly from these replicates. The total area of the orchard is about 23 dunums $\left(1\right.$ dunum $\left.=1000 \mathrm{~m}^{2}\right)$. One part $(14 \mathrm{du}$ nums) was irrigated by secondary treated wastewater (STWW) obtained from Sheikh Ejleen wastewater treatment plant while the second parts (9 dunums) was irrigated by freshwater (FW). Olive oil characteristic of the two parts were compared depending on technical lab analysis. Moreover, conditions to minimize the risk to public health and environment, and to promote safe application of wastewater reuse were discussed. Green ripe olives were harvested in October manually by hand, and milled after 5 - 6 days. Olive fruit samples for extraction were taken randomly by hand. Virgin olive oil was extracted by milling the selected olive fruit sample, followed by suction filtration with warm water, and then oil separation using separatory funnel. Effect of using treated wastewater in irrigation on selected olive oil quality parameters such as refractive index, free acidity, peroxide value, iodine value, trace metals and heavy metals was studied by comparing the results with reference sample used as control (extracted from trees irrigated with fresh water). Moreover, results of both olive oil samples (irrigated with treated wastewater or with fresh water) were compared with Palestinian and international standards.

\subsection{Water Crises and Quality in the Study Area}

In Gaza, as in Palestine, there is a large gap between water resources and demand [8]. Water resources available in Gaza are limited to groundwater from the Coastal Aquifer (98\%), or to water purchased from the Israeli water company (MEKOROT) (2\%). Approximately $52 \%$ of this available water is used in irrigation [17]. The Coastal Aquifer receives an annual average recharge of 55 $60 \mathrm{MCM} / \mathrm{y}$ mainly from rainfall, while the annual extraction rates from the aquifer is about $200 \mathrm{MCM}$. This unsustainable high rates of extraction has led to lowering the groundwater level, the gradual intrusion of seawater and up conning of the underneath saline groundwater. Therefore, water situation in Gaza is very bad in terms of quantity or quality. For example, the major parts of the aquifer have chloride concentration ranging between $600-2000 \mathrm{mg} / \mathrm{L}$, while along the coastal line chloride concentration exceeds $2000 \mathrm{mg} / \mathrm{L}$ and can reach more than $10,000 \mathrm{mg} / \mathrm{L}$ at some spots due to effect of seawater intrusion. Moreover, nitrate concentration in the municipal wells ranges from 50 to more than $200 \mathrm{mg} / \mathrm{L} .13 .3 \%$ of them had nitrate concentration less than $50 \mathrm{mg} / \mathrm{L}-\mathrm{WHO}$ allowable limit [17]. UN agencies and Coastal Municipal Water Utilities estimate 
the aquifer's supply water, suitable for human consumption, will disappear over the next five to ten years [18].

\section{Results and Discussion}

\subsection{Sheikh Ejleen Freshwater Characteristics}

About $90 \%$ to $95 \%$ of Coastal Aquifer-the municipal water supply for drinking in Gaza-is considered unfit for human consumption and not potable according to WHO standards [17] [18]. This is in agreement with the present work results obtained from groundwater sample analysis. The sample was taken from Sheikh Ejleen area and analyzed in our labs according to the standard methods for the examination of water and wastewater. Table 1 summarizes the physical and chemical analysis of freshwater in Sheikh Ejleen area as compared with Palestinian Standard (PS) for drinking water.

The results indicate that total dissolved solid (TDS), chloride, nitrate, potassium, calcium, and sodium contents in the drinking groundwater sample exceeding the Palestinian Standard acceptable limit. In fact, the groundwater aquifer is deteriorated because of pollution, increasing demand and the Israeli control of Palestinian water resources. As pumping increases, the aquifer becomes more deteriorated and more brackish.

\subsection{Sheikh Ejlenn Wastewater Treatment Plant Characteristics}

Various effluents samples were taken from Sheikh Ejleen wastewater treatment plant for physical, chemical and biological characteristics. Table 2 summarizes the effluent characteristics comparing with Palestinian Standard for treated wastewater quality reuse in agriculture.

Results in Table 2 show that the biological oxygen demand (BOD) is 60 mg. $\mathrm{l}^{-1}$, which indicates low quality effluent. In fact, the biotowers characterized by dark biofilms which is an indicator of inefficient bacterial growth, this most likely due to inoperative pretreatment unit process. Total dissolved solid, chloride, sodium and magnesium contents exceed the Palestinian Standard acceptable limit.

The study area can be irrigated by the treated wastewater (effluent) because the water table is deep; freshwater quality in aquifers is low and somewhere the water considered as brackish water; irrigated area is far away from residential areas and population; and it is closer to Sheikh Ejleen treatment plant.

Table 1. Physical and chemical analysis of freshwater in Sheikh Ejleen as compared with Palestinian Standard (PS) for drinking water.

\begin{tabular}{cccccccccc}
\hline & $\begin{array}{c}\text { TDS } \\
\mathrm{mg} \cdot \mathrm{l}^{-11}\end{array}$ & $\mathrm{pH}$ & $\begin{array}{c}\text { Chloride } \\
\mathrm{mg} \cdot \mathrm{l}^{-1}\end{array}$ & $\begin{array}{c}\text { Nitrate } \\
\mathrm{mg} \cdot \mathrm{l}^{-1}\end{array}$ & $\begin{array}{c}\text { Potassium } \\
\mathrm{mg} \cdot \mathrm{l}^{-1}\end{array}$ & $\begin{array}{c}\text { Magnesium } \\
\mathrm{mg} \cdot \mathrm{l}^{-1}\end{array}$ & $\begin{array}{c}\text { Calcium } \\
\mathrm{mg} \cdot \mathrm{l}^{-1}\end{array}$ & $\begin{array}{c}\text { Sodium } \\
\mathrm{mg} \cdot \mathrm{l}^{-1}\end{array}$ & $\begin{array}{c}\text { Detergent } \\
\mathrm{mg} \cdot \mathrm{l}^{-1}\end{array}$ \\
\hline $\begin{array}{c}\text { Sam- } \\
\text { ple }\end{array}$ & $1300 \pm 10$ & $6.9 \pm 0.1$ & $670 \pm 15$ & $61.0 \pm 0.1$ & $42.6 \pm 0.1$ & $97.0 \pm 0.8$ & $110.0 \pm 0.5$ & $398.0 \pm 9.5$ & $0.30 \pm 0.01$ \\
PS $^{*}$ & 1000 & $6.5-8.5$ & 250 & 50 & 10 & 100 & 100 & 200 & 0.5 \\
\hline
\end{tabular}

*: Palestinian Standard for drinking water (PS-41/2005) issued by Palestinian Standard Institute. 
Table 2. Physical and chemical analysis of Sheikh Ejleen effluent as compared with Palestinian Standard (PS) for irrigation of fruit trees.

\begin{tabular}{ccc}
\hline & Effluent & PS \\
\hline $\mathrm{pH}$ & $7.43 \pm 0.1$ & $6-9$ \\
TDS $\left(\mathrm{mg} \cdot \mathrm{l}^{-1}\right)$ & $2320 \pm 10$ & 1500 \\
TSS $\left(\mathrm{mg} \cdot \mathrm{l}^{-1}\right)$ & $35 \pm 1$ & 50 (C) quality \\
Chloride $\left(\mathrm{mg} \cdot \mathrm{l}^{-1}\right)$ & $1100 \pm 22$ & 400 \\
Sulfate $\left(\mathrm{mg} \cdot \mathrm{l}^{-1}\right)$ & $95 \pm 1$ & 500 \\
Sodium $\left(\mathrm{mg} \cdot \mathrm{l}^{-1}\right)$ & $600 \pm 35$ & 200 \\
Calcium $\left(\mathrm{mg} \mathrm{l} \mathrm{l}^{-1}\right)$ & $132 \pm 15$ & 400 \\
Magnesium $\left(\mathrm{mg} \cdot \mathrm{l}^{-1}\right)$ & $90 \pm 5$ & 60 \\
Nitrate $\left(\mathrm{mg} \cdot \mathrm{l}^{-1}\right)$ & $70 \pm 4$ & 50 \\
Total phosphorus $\left(\mathrm{mg} \cdot \mathrm{l}^{-1}\right)$ & $4.7 \pm 0.1$ & 30 \\
Potassium $\left(\mathrm{mg} \cdot \mathrm{l}^{-1}\right)$ & $26 \pm 1$ & 60 (D) quality \\
BOD $\left(\mathrm{mg} \cdot \mathrm{l}^{-1}\right)$ & $60 \pm 3$ & 150 \\
COD $\left(\mathrm{mg} \cdot \mathrm{l}^{-1}\right)$ & $185 \pm 5$ & 0.7 \\
Boron $\left(\mathrm{mg} \cdot \mathrm{l}^{-1}\right)$ & $0.50 \pm 0.01$ &
\end{tabular}

*: Palestinian Standard for using effluent in irrigation (PS-742/2003) of fruit trees issued by Palestinian Standard Institute.

\subsection{Effect of Treated Wastewater on Soil Parameters and Extracted Olive Oil Quality}

The crops are susceptible to heavy metals if, there is a source of heavy metals that either natural or artificial reaches wastewater. Compatible conditions stimulate heavy metals to release such as low $\mathrm{pH}$ is not exist in Gaza because there are no heavy industries to release heavy metals. On the contrary, high $\mathrm{pH}$, in Gaza soil due to the presence of carbonate and bicarbonate, contributes to heavy metals fixation. Therefore, heavy metals, if found, will not affect the crops. However, periodic analytical tests must be done in order to avoid future accumulative effects. This is in agreement with data in Table 3 and Table 4 for soil and olive oil analysis, respectively.

Using treated wastewater in irrigation improves soil properties in term of organic matter content and cation exchange capacity as shown in Table 3. Soil analysis for both Shetawe's farm (irrigated by effluent) and reference orchards (irrigated by freshwater) indicated that soil texture was Sandy Loam. There was no effect for irrigation by effluent on soil $\mathrm{pH}$ and electrical conductivity (EC) in comparison with soil irrigated with freshwater (Table 3). Furthermore, there is no significant difference between heavy metals concentration, such as boron, manganese, nickel, lead, and cadmium, in both of the two soil samples. Therefore, irrigation using treated wastewater shows no significant addition of heavy metals to the soil due to the reasons mentioned previously, in addition to the fact that Sheikh Ejleen treatment plant is almost exclusively of domestic origin, with little industrial contribution. 
Table 3. Soil physical and chemical properties of soil samples from Shetawe's farm area and the reference orchard area.

\begin{tabular}{|c|c|c|}
\hline & Soil irrigated by effluent & Soil irrigated by freshwater \\
\hline Clay (\%) & $17.5 \pm 0.1$ & 17.5 \\
\hline Silt (\%) & $10.0 \pm 0.1$ & 15.0 \\
\hline Sand (\%) & $72.5 \pm 0.1$ & 67.5 \\
\hline $\mathrm{pH}$ & $8.149 \pm 0.010$ & 8.295 \\
\hline TDS $\left(\mathrm{mg} \cdot \mathrm{l}^{-1}\right)$ & $460 \pm 8$ & 448 \\
\hline $\mathrm{EC}(\mu \mathrm{S} / \mathrm{cm})$ & $767 \pm 15$ & 746 \\
\hline Organic matter (\%) & $3.55 \pm 0.10$ & 1.27 \\
\hline Calcium carbonate (\%) & $8.2 \pm 0.1$ & 11 \\
\hline Cation exchange capacity (meq/100 g) & $0.532 \pm 0.010$ & 0.238 \\
\hline Chloride $\left(\mathrm{mg} \cdot \mathrm{kg}^{-1}\right)$ & $188 \pm 3$ & 125 \\
\hline Sodium $\left(\mathrm{mg} \cdot \mathrm{kg}^{-1}\right)$ & $200 \pm 4$ & 170 \\
\hline Calcium $\left(\mathrm{mg} \cdot \mathrm{kg}^{-1}\right)$ & $27.0 \pm 0.1$ & 20 \\
\hline Magnesium $\left(\mathrm{mg} \cdot \mathrm{kg}^{-1}\right)$ & $20.0 \pm 0.1$ & 12 \\
\hline Nitrate $\left(\mathrm{mg} \cdot \mathrm{kg}^{-1}\right)$ & $19.0 \pm 0.1$ & 27 \\
\hline Potassium $\left(\mathrm{mg} \cdot \mathrm{kg}^{-1}\right)$ & $9.0 \pm 0.1$ & 15 \\
\hline Total alkalinity $\left(\mathrm{mg} \cdot \mathrm{kg}^{-1}\right)$ & $92.0 \pm 0.1$ & 79 \\
\hline Carbonate alkalinity $\left(\mathrm{mg} \cdot \mathrm{kg}^{-1}\right)$ & Not detected & Not detected \\
\hline Phosphate $\left(\mathrm{mg} \cdot \mathrm{kg}^{-1}\right)$ & Not detected & Not detected \\
\hline Manganese $\left(\mathrm{mg} \cdot \mathrm{kg}^{-1}\right)$ & $24.0 \pm 0.1$ & 2.1 \\
\hline Boron $\left(\mathrm{mg} \cdot \mathrm{kg}^{-1}\right)$ & $7.9 \pm 0.1$ & 0.7 \\
\hline Cadmium (mg.kg $\left.{ }^{-1}\right)$ & $0.30 \pm 0.01$ & 0.2 \\
\hline $\operatorname{Zinc}\left(\mathrm{mg} \cdot \mathrm{kg}^{-1}\right)$ & $41.0 \pm 0.1$ & 18 \\
\hline Nickel (mg. $\left.\mathrm{kg}^{-1}\right)$ & $2.20 \pm 0.01$ & 3.2 \\
\hline
\end{tabular}

Table 4. Quality characteristics of olive oil extracted from olive fruits irrigated by Sheikh Ejleen effluent and reference orchard as compared with Palestinian Standard (PS).

\begin{tabular}{cccc}
\hline & $\begin{array}{c}\text { Trees irrigated by } \\
\text { effluent }\end{array}$ & $\begin{array}{c}\text { Trees irrigated by } \\
\text { freshwater }\end{array}$ & PS* \\
\hline Acidity expressed as oleic acid $(\%)$ & $3.8 \pm 0.1$ & $3.14 \pm 0.1$ & 3.3 \\
Peroxide value (meq. $\left.\mathrm{O}_{2} \cdot \mathrm{Kg}^{-1}\right)$ & $20.2 \pm 0.3$ & $25.8 \pm 0.4$ & 20 \\
Iodine value $\left(\mathrm{g} \mathrm{I}_{2} / 100 \mathrm{~g} \cdot \mathrm{oil}\right)$ & $96 \pm 2$ & $92 \pm 2$ & $75-94$ \\
Refractive index at $20^{\circ} \mathrm{C}$ & $1.4697 \pm 0.0003$ & $1.4705 \pm 0.0005$ & $1.4677-1.4705$ \\
Relative density at ${ }^{\circ} \mathrm{C}$ & $0.907 \pm 0.001$ & $0.906 \pm 0.001$ & $0.910-0.916$ \\
Iron $\left(\mathrm{mg} \cdot \mathrm{kg}^{-1}\right)$ & $2.80 \pm 0.01$ & $3.10 \pm 0.01$ & 5.0 \\
Lead $\left(\mathrm{mg} \cdot \mathrm{kg}^{-1}\right)$ & $0.09 \pm 0.01$ & $0.08 \pm 0.01$ & 0.1 \\
Copper $\left(\mathrm{mg} \cdot \mathrm{kg}^{-1}\right)$ & $0.01<$ & $0.01<$ & 0.1 \\
Cadmium $\left(\mathrm{mg} \cdot \mathrm{kg}^{-1}\right)$ & $0.01<$ & $0.01<$ & 0.1 \\
\hline
\end{tabular}

*: Palestinian Standard for olive oil (PS-188/1997) issued by Palestinian Standard Institute. 
Table 4 shows olive oil parameter obtained from analysis of olive oil extracted from olive fruits irrigated by Sheikh Ejleen effluent and reference orchard (irrigated by freshwater) as compared with Palestinian Standard (PS). Obtained results indicate that most of olive oil quality parameters fall within the standard limit values. Moreover, trace elements concentration is less than the Palestinian Standards acceptable limit. This is in line with the domestic origin of the influents, of Sheikh Ejleen treatment plant, which contains little industrial contribution.

There are no significant differences of quality parameters for olive oil extracted from the fruits of both irrigation types. However, Acidity (expressed as oleic acid) of olive oil extracted from fruits of the trees irrigated with treated wastewater has higher value than the standard limit, it's likely because of using careless extraction methods for pressing the fruits of the trees that irrigated with wastewater. On the other hand, peroxide values for olive oil extracted from fruits of the trees irrigated with freshwater is higher than that extracted from fruits of the trees irrigated with effluent, the values exceed the standard allowable limit, it's likely because it's lower in oleic acid or less monounsaturated than polyunsaturated fatty acids. This renders olive oil less resistant to oxidation.

Conditions in the study area such as low quality freshwater, availability of Sheikh Ejleen treatment plant which provides close source of treated wastewater, and the absence of heavy metals due to domestic origin of influent, motivate using of the effluent in irrigation. On the other hand, the concerns for human health and the environment are the most important constraints in the reuse of treated wastewater. Health concerns can be overcome by raising public awareness, and by developing and implementing reuse standards. For example, irrigation of olive trees must be stopped for a month before harvest time, and, fallen fruits should not be taken. Moreover, the possibilities of pathogens passing from the treated wastewater to vegetables or fruits can be minimized by keeping an appropriate distance between the treated wastewater and the fruits; using subsurface drip irrigation; and by disinfection of the treated wastewater.

\section{Conclusions}

Physical and chemical analysis of drinking groundwater in the study area-Sheikh Ejleen, indicate that concentration of the quality parameters such as total dissolved solid, chloride, sodium, calcium, potassium and nitrate exceed Palestinian standards acceptable limit. In fact, there is no significant difference between effluent quality and freshwater low quality which can be considered as brackish water.

Soil samples analysis show that using treated wastewater in irrigation improves soil properties in term of organic matter content and cation exchange capacity, and there is no significant addition of heavy metals such as boron, manganese, nickel, lead, and cadmium to the soil.

Comparing quality characteristics of olive oil extracted from trees irrigated by 
effluent or irrigated by freshwater shows that there is no signification difference, and values are fallen within the acceptable standard limit values.

\section{Acknowledgements}

The authors thank Eng. Haneen N. Al-Sbihi and Eng. Yousra A. Abu-Sharekh for the help in samples collection and data analysis during their graduation project in the Environmental Engineering Department-Islamic University of Gaza. The project Water and Livelihood Initiatives (WLI)-ICARDA is highly acknowledged for supporting this work to be published.

\section{References}

[1] Ministry of Agriculture (2010) Agricultural Sector Strategy 2011-2013 "A Share Vision". Ministry of Agriculture, Ramallah.

[2] Ministry of Agriculture (2013) National Agricultural Sector Strategy 2014-2016 "Resilience and Development". Ministry of Agriculture, Ramallah.

[3] International Trade Centre (ITC), Ministry of National Economy (MoNE), and Palestine Trade Center (PalTrade) (2010) National Export Strategy "Olive Oil Sector Export Strategy 2014-2018”. Ministry of National Economy, Ramallah.

[4] Meneley, A. (2011) Blood, Sweat and Tears in a Bottle of Palestinian Extra-Virgin Olive Oil. Food Culture Society, 14, 275-291. https://doi.org/10.2752/175174411X12893984828872

[5] Joint Advocacy Initiative (JAI) (2016) The Olive Tree Campaign "Keep Hope Alive" Reports 2013-2014 \& 2014-2015. East Jerusalem. http://www.jai-pal.org/

[6] Isaac, J., Ghattas, R. and Hrimat, N. (2015) Palestinian Agricultural Production and Marketing between Reality and Challenges: Executive Summary for a Research Study "Food Production-Consumption Assessment to Improve Sustainable Agriculture and Food Security in the West Bank-Palestine". The Applied Research Institute-Jerusalem (ARIJ), Bethlehem.

[7] UNCTAD (2015) The Besieged Palestinian Agricultural Sector. United Nation, New York and Geneva.

[8] Baalousha, H. (2006) Desalination Status in the Gaza Strip and Its Environmental Impact. Desalination, 196, 1-12. https://doi.org/10.1016/j.desal.2005.12.009

[9] Barghouthi, Z. and Gerstetter, C. (2012) Climate Change and Opportunities to Reduce Its Impacts on Agriculture and Water, and Conflict Risks in Palestine. In: Rahil, M. and Natsheh, B., Eds., Water Crises and Agricultural Development in Palestine, Palestine Technical University-Kadoorie, Tulkarm, 39-52.

[10] El-Jazairi, L. (2010) The Road to Olive Farming: Challenges to Developing the Economy of Olive Oil in the West Bank. Oxfam GB, Oxford.

[11] Bahri, A. (2008) Water Reuse in Middle Eastern and North African Countries. In: Jimenez, B. and Asano, D., Eds., Water Reuse: An International Survey of Current Practice, Issues and Needs, IWA Publishing, London, 27-47.

[12] Barghouthi, Z. (2010) Water Scarcity and Opportunities for Saline Water Use in Palestine. In: Sustainable Management of Saline Waters and Salt-Affected Soils in Agriculture: Proceeding of the Second Bridging Workshop, Qadir, M., Wichelns, D., Oster, J., Jacobsen, S.-E., Basra, S.M.A. and Choukr-Allah, R., Eds., ICARDA \& IWMI, Aleppo, 85-91. 
[13] Kfouri, C., Mantovani, P. and Jeuland, M. (2009) Water Reuse in MNA Region: Constrains, Experience, and Policy Recommendations. In: Jagannathan., N.V., et al., Eds., Water in the Arab World: Management Perspectives and Innovations, The World Bank, Middle East and North Africa Region, Washington DC, 447-477.

[14] Palestinian Central Bureau of Statistics (PCBS) (2016) Palestinian at the End of 2016. PCBS, Ramallah.

[15] Consulting Engineering Center-Palestine (2016) Assessment of Wastewater Treatment Technologies in Palestine Report. Personal contact with Ministry of Agriculture, Ramallah.

[16] APHA, American Public Health Association (1998) Standard Methods for the Examinations of Water and Wastewater. 20th Edition, Washington DC, 20005-2605.

[17] Palestinian Water Authority (PWA) (2014) Gaza Water Resources Status Report, 2013/2014. PWA, Ramallah.

[18] UNICEF and Palestinian Hydrology Group (PHG) (2010) Water, Sanitation and Hygiene Household Survey Gaza Report. PHG, Ramallah. 